University of Nebraska - Lincoln

DigitalCommons@University of Nebraska - Lincoln

1975

\title{
Age Determination of Female Redhead Ducks
}

\author{
Charles W. Dane \\ USGS Northern Prairie Wildlife Research Center \\ Douglas H. Johnson \\ USGS Northern Prairie Wildlife Research Center, Douglas_H_Johnson@usgs.gov
}

Follow this and additional works at: https://digitalcommons.unl.edu/usgsnpwrc

Part of the Other International and Area Studies Commons

Dane, Charles W. and Johnson, Douglas H., "Age Determination of Female Redhead Ducks" (1975). USGS Northern Prairie Wildlife Research Center. 209.

https://digitalcommons.unl.edu/usgsnpwrc/209

This Article is brought to you for free and open access by the US Geological Survey at DigitalCommons@University of Nebraska - Lincoln. It has been accepted for inclusion in USGS Northern Prairie Wildlife Research Center by an authorized administrator of DigitalCommons@University of Nebraska - Lincoln. 


\title{
AGE DETERMINATION OF FEMALE REDHEAD DUCKS
}

\author{
CHARLES W. DANE, U.S. Fish and Wildlife Service, Northern Prairie Wildlife Research Center, Jamestown, North Dakota \\ 58401 \\ DOUGLAS H. JOHNSON, U.S. Fish and Wildlife Service, Northern Prairie Wildlife Research Center, Jamestown, North \\ Dakota 58401
}

\begin{abstract}
Eighty-seven fall-collected wings from female redhead ducks (Aythya americana) were assigned to the adult or juvenile group based on "tertial" and "tertial covert" shape and wear. To obtain spring age-related characters from these fall-collected groupings, we considered parameters of flight feathers retained until after the first breeding season. Parameters measured included: markings on and width of greater secondary coverts, and length, weight, and diameter of primary feathers. The best age categorization was obtained with discriminant analysis based on a combination of the most accurately measured parameters. This analysis, applied to 81 wings with complete measurements, resulted in only 1 being incorrectly aged and 3 placed in a questionable category. Discriminant functions used with covert markings and the three 5th primary parameters were applied to 30 known-age juvenile, handreared redhead females; 28 were correctly aged, none was incorrectly aged, and only 2 were placed in the questionable category.
\end{abstract}

J. WILDL. MANAGE. 39(2):256-263

To estimate the production of a given waterfowl breeding population, information is needed on the expected productivity of various age cohorts. Of particular importance is the productivity of yearling birds compared with that of older females. Most of the techniques used to distinguish firstyear birds from adults are not valid for most ducks in the spring, because adult growth and sexual development have been attained and identifying feathers have been replaced. Even with those external characters of waterfowl that are age-related in in the spring (e.g., eye color [Trauger 1974] and bill spots [Kuroda 1937, Dane 1968]), the overlap between adult and first-year birds diminishes the usefulness of these methods.

Age determination techniques have been improved by using combinations of more than one age-related character. This has been accomplished either by plotting both parameters from each individual on a twodimensional graph '(Wishart 1969, Greenberg et al. 1972), by use of a dichotomous key (Carney and Geis 1960, Carney 1964), or in a subjective manner (Smart 1962).
For distinguishing between first-year and older redhead females in the breeding season, we have used a combination of parameters obtained from selected primaries and greater upper secondary coverts (exclusive of proximal coverts, i.e., "tertial" coverts). Measurements of these parameters were used to establish discriminant functions for each age group, thereby utilizing several parameters simultaneously.

Of the many different feathers that have been used as age indicators, tail and wing feathers have been preferred by biologists because of the pattern and timing of the molt. Primaries, secondaries (except for proximal secondaries, i.e., "tertials") and their coverts are retained until the prebasic II molt (Humphrey and Parkes 1959) following the first breeding season in most ducks (e.g., gadwall [Anas strepera] [Oring 1968], blue-winged teal [A. discors] [Greij 1969], common merganser [Mergus merganser] [Erskine 1971], and redhead [Weller 1970]). Exceptions may include the ruddy duck (Oxyura jamaicensis) (Humphrey and Clark 1964) and the black-headed duck (Heteronetta atrica- 
pilla) (Weller 1967). Therefore, use of fall-obtained, age-related differences in these feathers should provide valid age characters in the spring.

Markings on wing coverts have been used in the spring for age determination of firstyear ducks, including gadwall (Oring 1968), common merganser (Anderson and Timken 1971), redhead (Smart 1962), bluewinged teal (Dane 1968), and certain other ducks (Carney 1964). Differences in primary feather length between first-year and older ducks have been recognized for the blue-winged teal (Dane 1968), and certain other waterfowl (Carney 1964).

Special acknowledgment is due G. Smart, who, having spent several years studying redheads, made the initial suggestion to examine covert markings of redheads, and who assigned hunter-submitted redhead wings to "known" age categories based upon "tertial" and "tertial covert" shape and wear. We appreciate the careful work of C. Braeger, T. Dwyer, and V. Howard, who made most of the measurements used in this study. F. Lee supervised the rearing of the known-age juvenile redheads. We thank D. Gilmer, G. Smart, and L. Oring for their review of the manuscript.

\section{METHODS}

Eighty-seven fall-collected wings were selected at the Mississippi Flyway "wingbee" and assigned to the adult or juvenile category based on "tertial" and "tertial covert" shape and wear (Carney 1964). These characters are considered to be reliable indicators of age in the fall, but not in the spring after the "tertials" and "tertial coverts" are replaced in the prealternate I molt. Resultant "known-age" groupings consisted of 37 adults and 50 juveniles.

Parameters of flight feathers retained until after the first breeding season were examined. These parameters included markings on and width of greater upper secondary coverts, and length, weight, and diameter of primary feathers. Covert markings, and 5th primary length, weight, and diameter also were obtained in the fall from 37 juvenile redheads reared at the Northern Prairie Wildlife Research Center in 1972.

Greater upper secondary coverts were examined for the feathers possessing the most characteristic marking (Fig. 1). On the basis of this marking the covert was assigned to one of the following categories: well flecked, moderately flecked, slightly flecked, no marking, indication of bar, light thin bar, light wide bar, moderately barred, and heavily barred. A covert marking score was obtained by rating these categories from 1 to 9 in the above order.

The 11th, 12th, and 13th greater secondary coverts were pulled and the width of each recorded. This measurement, to the nearest $0.5 \mathrm{~mm}$, was taken $3 \mathrm{~mm}$ below the tip of the shaft after the feather was flattened, the shaft straightened, and the bars preened into normal position (Fig. 2). Because this method of measurement also provided an assessment of covert shape, it accentuated the difference between birds before and after their first postnuptial molt.

The 12th and 13th greater secondary coverts were better age indicators than the 11th, and, because of the possibility of the 13th being replaced during the prenuptial molt (prealternate I molt), the 12th was selected for use in subsequent evaluation. The 14th greater secondary covert “. . . overlaps both [number] 13 and 15 and marks the beginning of contrary overlap...." (Humphrey and Clark 1961:373). Although this covert might be considered as the division between greater secondary coverts and "tertial" coverts, Humphrey and Clark (1961) regarded secondaries numbered 1 to 12 as speculum; number 13 and its associated covert have been observed 


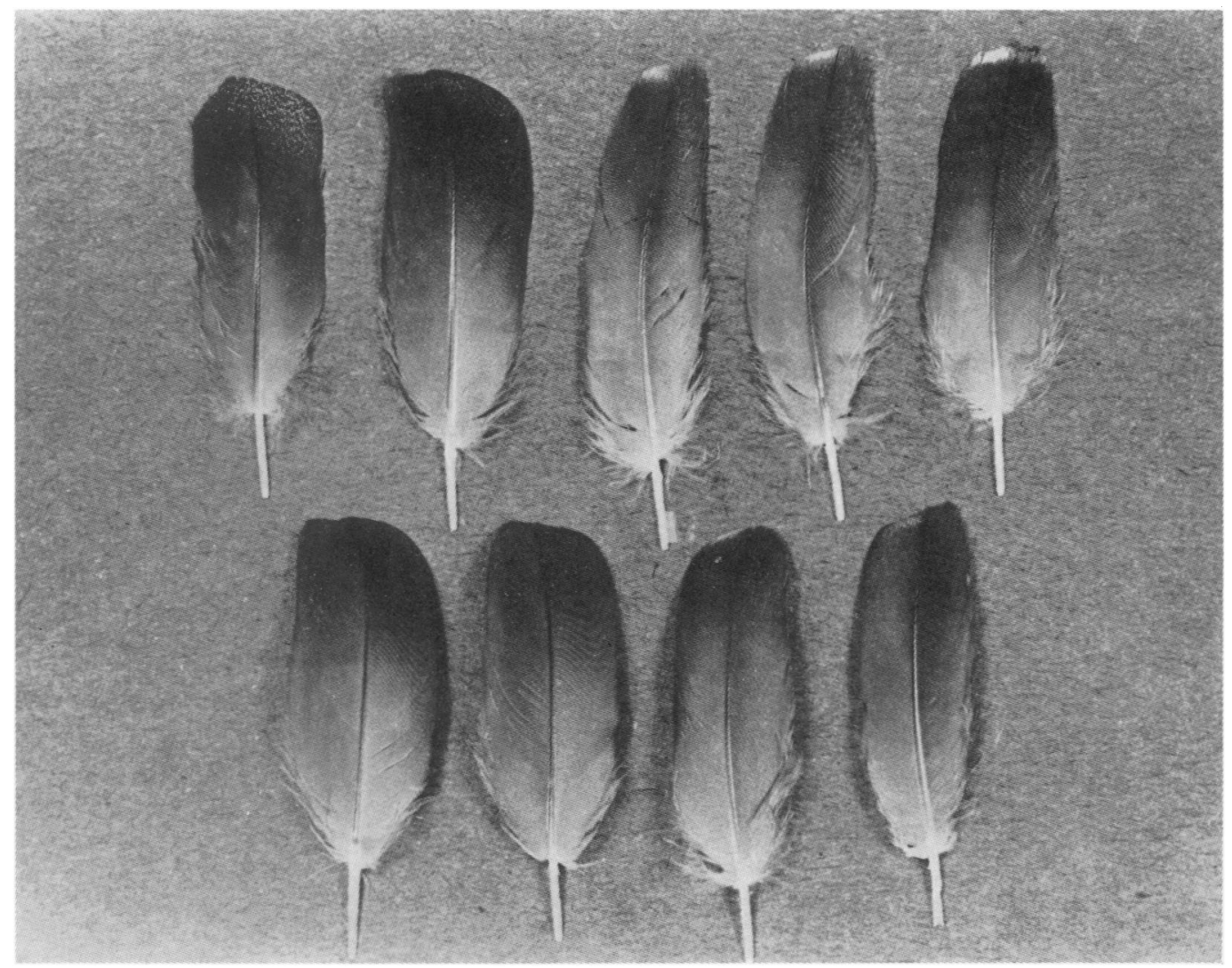

Fig. 1. Flecking and barring on greater secondary coverts as an age character of redhead duck females. Upper row from left to right pictures definite adult markings of well flecked and moderately flecked, and definite juvenile markings of light wide bar, moderately barred, and heavily barred. The lower row from left to right depicts intermediate markings of slightly flecked, no marking, light thin bar, and indication of bar.

to be replaced in redheads before the breeding season. Among 10 hand-reared, first-year redhead females examined on 30 May, the most distal greater secondary covert that had been replaced was the 13th (replaced by 5 females); for the others the 14th or 15th was the most distal new covert. There was no indication of progressive dropping of more distal coverts between 28 March and 30 May. "Tertial" coverts (i.e., 13th or 14th and more proximal greater secondary coverts) are reportedly replaced in the prealternate molts (Oring 1968, Erskine 1971).
The 1st, 5th, and 9th primary feathers were pulled from each wing. Primary feather weight was measured to the nearest mg. Primary length was measured from tip of quill to tip of vane to the nearest $0.5 \mathrm{~mm}$ after the feather was flattened against a millimeter ruler and the sidewards bend of the shaft was straightened. Before primary diameters were measured, feathers were dried for $24 \mathrm{~h}$ at $50 \mathrm{C}$ in a forced-air oven, as suggested by Greenberg et al. (1972). Primary diameters were measured to the nearest $0.01 \mathrm{~mm}$ with a dial indicator pocket gauge with flat surface tips. Shaft 


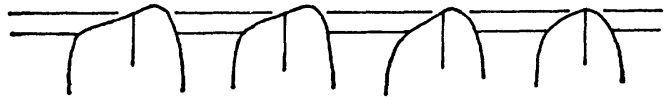

Fig. 2. Feather tips show position of covert for measurement. The two 12th greater secondary coverts on the left are from adult female redheads while those on the right are from juvenile females. The tip of the rachis is placed on the upper line and covert width measurement made 3 $\mathrm{mm}$ below, as indicated by the lower line. Because of the manner in which this measurement is made, it also provides an assessment of covert shape.

diameters were measured in the plane of the vane at the superior umbilicus and perpendicular to this plane at the same point. The average of the two measurements appeared to be the best diameter-related indicator of age and was used in discriminant analysis.

Two 9th primaries could not be used because a portion of the quill was not translucent, indicating that they were not fully grown. One 5th primary feather was abnormally short, as indicated by the length of surrounding primaries, and another was broken. Length and weight measurements on these feathers were excluded. Some 5th primary diameters were distorted because of compression in removal, but the average of the two diameter measurements was considered reasonably accurate. Greater coverts from two juveniles and seven knownage juveniles were not measured because of feather wear or loss. Because of the incomplete set of measurements on some individuals, the usable sample for discriminant analysis was reduced to 35 adults, 46 juveniles of unknown age, and 30 knownage juveniles. The 1st primaries were collected without identifying the individual from which it was collected; thus, although the degree of separation provided by this character alone could be made, it could not be used in conjunction with other parameters.

Frequency distributions of each param- eter, including the scores for covert marking for adult and juvenile categories, were plotted and appeared to be normally distributed. We thus felt justified to use them in discriminant analysis. Discriminant analysis (e.g., Tatsuoko 1970, Anderson 1958) is a technique appropriate for distinguishing groups of individuals on the basis of linear combinations of measurements. It is a multivariate procedure that takes into consideration the differing precisions of, and intercorrelations among, the parameters.

The computer program (Dixon 1968: 214a) used in this study performs the discriminant analysis procedure in a stepwise manner, entering parameters one at a time. The parameters enter in order of their ability to distinguish the age groups, conditional upon the parameters already included. The analysis also provides for each individual two "probabilities," reflecting the likelihood that it belongs to the juvenile and to the adult age class. An individual was placed in the "questionable" category if its probability of belonging to either group was less than 80 percent.

\section{RESULTS}

Average parameter values for fall-taken adults and juveniles are shown in Table 1. When ranked according to the $F$ statistic for comparison of means between age classes, the best single parameter for age determination was covert width, followed by covert marking and 5th primary weight, which were about equal, and, in descending order, 9th primary diameter, 5th primary diameter, 5 th primary length, 9 th primary weight, and 9th primary length. When only covert marking and 5th primary parameters of known-age juveniles were considered, covert marking was the best single parameter for age determination, followed by 5 th primary weight, 5th primary diameter, and 5th primary length. 
Table 1. Summary statistics for covert and flight feather characteristics $^{a}$ in a heterogeneous sample of 87 fall-taken redhead wings and 37 wings of known-age juveniles.

\begin{tabular}{|c|c|c|c|c|}
\hline Parameter & $\begin{array}{c}\text { Sample } \\
\text { size }\end{array}$ & Mean & $\begin{array}{l}\text { Standard } \\
\text { deviation }\end{array}$ & $F^{\mathbf{b}}$ \\
\hline \multicolumn{5}{|l|}{ Covert width } \\
\hline Adult $^{\mathrm{c}}$ & 37 & 13.11 & 1.04 & \multirow[t]{2}{*}{224.64} \\
\hline Juvenile $^{c}$ & 48 & 10.12 & 0.80 & \\
\hline \multicolumn{5}{|l|}{ Covert marking } \\
\hline Adult & 37 & 2.65 & 1.16 & \multirow[t]{3}{*}{126.98} \\
\hline Juvenile & 50 & 6.32 & 1.71 & \\
\hline Known-age juvenile & 30 & 6.67 & 1.58 & \\
\hline \multicolumn{5}{|l|}{ 5th Primary weight } \\
\hline Adult & 36 & 182.08 & 9.02 & \multirow[t]{3}{*}{122.03} \\
\hline Juvenile & 49 & 159.94 & 9.21 & \\
\hline Known-age juvenile & 37 & 161.43 & 7.45 & \\
\hline \multicolumn{5}{|l|}{ 9th Primary diameter } \\
\hline Adult & 36 & 2.735 & 0.072 & \multirow{2}{*}{112.92} \\
\hline Juvenile & 50 & 2.593 & 0.052 & \\
\hline \multicolumn{5}{|l|}{ 5th Primary diameter } \\
\hline Adult & 35 & 2.606 & 0.066 & \multirow[t]{3}{*}{88.67} \\
\hline Juvenile & 50 & 2.459 & 0.074 & \\
\hline Known-age juvenile & 37 & 2.446 & 0.059 & \\
\hline \multicolumn{5}{|l|}{ 5th Primary length } \\
\hline Adult & 36 & 144.40 & 3.16 & \multirow[t]{3}{*}{88.56} \\
\hline Juvenile & 49 & 138.37 & 2.73 & \\
\hline Known-age juvenile & 37 & 139.85 & 2.52 & \\
\hline \multicolumn{5}{|l|}{ 9th Primary weight } \\
\hline Adult & 35 & 265.68 & 13.68 & \multirow[t]{2}{*}{82.02} \\
\hline Juvenile & 49 & 240.65 & 11.57 & \\
\hline \multicolumn{5}{|l|}{ 9th Primary length } \\
\hline Adult & 35 & 167.28 & 4.38 & \multirow[t]{2}{*}{33.25} \\
\hline Juvenile & 49 & 162.37 & 3.42 & \\
\hline
\end{tabular}

a Linear measurements in $\mathrm{mm}$; weights in $\mathrm{mg}$; covert marking coded 01 for well flecked, 02 for moderately flecked, 03 for slightly flecked, 04 for no marking, 05 for indication of bar, 06 for light thin bar, 07 for light wide bar, 08 for moderately barred, and 09 for heavily barred ( see Fig. 1).

b Test of equality of means of fall-collected adult and juvenile wings from "wing-bee." Degrees of freedom are 1 for the numerator and adult sample size + juvenile sample size for the denominator -2 .

c As determined in fall "wing-bee."

If frequency distributions for each age class and each parameter were visually examined, one could subjectively set limits so that parameters above the upper selected demarcation level would be considered indicative of adult hens after the prebasic II molt, and parameters below the lower demarcation line would be considered indicative of hens prior to the prebasic II molt.
The subjectively set limits were between two and three standard deviations above the juvenile means or below the adult means. All except 10 of the 87 females possessed at least one character that would have permitted correct age categorization of the individual, and only 1 of the 10 would have been assigned to an incorrect age category.

The best age categorization was obtained by using discriminant analysis with the seven most accurately measured parameters (5th primary length and weight, 9th primary length, weight, and diameter, and covert marking and width). Table 2 indicates the coefficients of each parameter in the discriminant functions. Of the 81 birds with all 7 parameters available and therefore usable in the analysis, only 1 was incorrectly assigned and only 3 were placed in the questionable category. Thirty-two of the 35 adults were assigned to the adult category with a 98.8 - to 100 -percent probability, 1 with 93.0-percent, 1 with 41.4percent (i.e., considered questionable), and 1 with 15.6-percent (incorrectly classified if initial age determination was correct). Forty-three of the 46 juveniles were assigned to the juvenile category with a 99.5- to 100-percent probability, 1 with 90.3-percent, and 1 each with 59.6- and 34.9-percent (considered questionable).

When either the four most "stable" parameters (those considered least likely to change with time-covert marking, 5th primary length, 9th primary length, and 9th primary diameter) or the five most "definitive" parameters (those with highest $F$ values-covert marking, covert width, 5th primary length, 5th primary weight, and 9th primary diameter) were used to establish the discriminant functions, only two individuals were assigned to the incorrect age class and five were considered questionable. Coefficients of each parameter 
Table 2. Coefficients in the discriminant functions for adult and juvenile wings of female redheads based on the four most stable and seven most accurately measured variables.

\begin{tabular}{|c|c|c|c|c|c|c|c|c|}
\hline \multirow[b]{2}{*}{ Age class } & \multicolumn{2}{|c|}{ Covert } & \multicolumn{2}{|c|}{ Fifth primary } & \multicolumn{3}{|c|}{ Ninth primary } & \multirow[b]{2}{*}{ Constant } \\
\hline & Marking & Width & Weight & Length & Weight & Length & Diameter & \\
\hline Adult & 3.587 & & & 10.623 & & 1.887 & 481.361 & $-1,587.506$ \\
\hline Juvenile & 5.190 & & & 9.738 & & 2.330 & 452.970 & $-1,466.724$ \\
\hline Adult & 6.011 & 5.513 & -5.973 & 28.601 & -3.019 & 3.604 & $1,016.465$ & $-2,854.176$ \\
\hline Juvenile & 7.474 & 2.640 & -6.384 & 28.288 & -2.754 & 3.778 & 992.746 & $-2,744.996$ \\
\hline
\end{tabular}

in the discriminant functions when the four most stable parameters were used are provided in Table 2.

When discriminant functions based on covert markings and the three 5th primary parameters of fall-collected adult and juvenile wings were applied to 30 juvenile hand-reared females, 28 were correctly aged, none was incorrectly aged, and only 2 were placed in the questionable category.

\section{DISCUSSION}

Previous efforts to determine age of spring-caught redheads have not provided well defined results. Weller (1957) noted that adult female redheads usually have more white frosting on the scapulars, but that it is difficult to distinguish yearling from older redhead females in the spring because adult and juvenile wings are similar. Smart (1962) used a complex of plumage characters to separate yearling female redheads from those that were more than one year old in the spring. Plumage characters referred to included presence of white feathers on the back of the head (also mentioned by Weller 1957), white flecking or light edge on distal end of the greater coverts, and wear of plumage in the areas of the rump and inner secondaries. Without reporting the number of birds examined or the data on an individual basis, Smart stated that female redheads usually could be classified correctly as yearling or older birds in the spring.
Wishart (1969) and Greenberg et al. (1972) used the 1st primary of ring-necked pheasants (Phasianus colchicus) because it matures first (at a time when the body size difference between molting young and molting adult birds is greater). In waterfowl there is a basis for size parameters of the 5 th primary providing a better indicator of age. The three proximal primaries of redheads harden at about the same time (Weller 1957), but the 2nd primary usually matures first, and the 4th and 5 th primaries within 3 or 4 days. Any shaft diameter differences due to the size of the bird at the time it is growing feathers would be expected to be the same for 1st and 5th primaries. The latter being longer than the 1st primary allows for greater differences between yearling and adult feather length and weight. Thus, the 5th primary would be expected to accentuate any combined diameter, length, and weight function differences. The diameter measurement might be more precise if a knife-type edge was used on the thickness indicator gauge.

Because average primary feather weights reported in this paper were obtained a few years after the birds were killed, weights may be less than those from freshly plucked primaries if desiccation of feathers occurs. The average weight of freshly plucked 5th primaries from hand-reared juveniles was slightly greater than the average of stored juvenile primaries, 161.4 and $159.7 \mathrm{mg}$, respectively. Although the difference may 
have been due to differences in drying time or method of rearing, it was not great enough to prevent correct age classification of 28 of 30 hand-reared juveniles. Weight measurements also are subject to variation during the year as a result of feather wear.

Among hand-reared redheads, the greater upper secondary coverts proximal to the 13th or 14th covert were replaced during the prealternate I molt. Therefore, parameters of the 12th greater secondary coverts obtained in the fall should be valid age indicators in the spring, although feather wear on some spring-caught female redheads may preclude classification of markings. Greater secondary coverts of juvenile males may possess both flecking and bar markings.

The tip of the covert quill is attached just above its secondary feather quill; however, if the collector determines the number of the desired covert by counting secondaries, he should be aware of the absence of what would be secondary number 5 even though the 5th covert is present (Humphrey and Clark 1961). Thus, the quill of the 12th covert actually is attached near the base of the 11th secondary (or secondary number 12 using the numbering system that omits number 5).

The parameters used in this study from fall-collected birds are considered meaningful for spring-collected birds. The use of several age-correlated parameters in discriminant analysis increases the number of individuals that can be correctly classified as first-year or older birds. The coefficients provided in Table 2 permit use of this technique to categorize unknown age individuals through use of all seven parameters evaluated in this study or more conservatively through use of only the four most "stable" parameters.

Needed feathers for measurement can be obtained from live birds, and later anal- ysis will permit age categorization. The method should be appropriate for other waterfowl that are difficult to classify as first year or older birds in the spring and should aid in the evaluation of the effect of age on reproductive performance.

\section{LITERATURE CITED}

Anderson, B. W., ANd R. L. Tmmken. 1971. Age and sex characteristics of common mergansers. J. Wildl. Manage. 35(2):388-393.

Anderson, T. W. 1958. An introduction to multivariate statistical analysis. John Wiley and Sons, New York. 374pp.

Carney, S. M. 1964. Preliminary keys to waterfowl age and sex identification by means of wing plumage. U.S. Fish Wildl. Serv. Spec. Sci. Rep. Wildl. 82. 47pp.

- ANd A. D. Geis. 1960. Mallard age and sex determination from wings. J. Wildl. Manage. 24(4):372-381.

DANE, C. W. 1968. Age determination of bluewinged teal. J. Wildl. Manage. 32(2):267274.

Dixon, W. J., ed. 1968. BMD biomedical computer programs. 2nd ed. University of California Press, Berkeley and Los Angeles. 600 pp.

Erskine, A. J. 1971. Growth and annual cycle in weights, plumages and reproductive organs of Goosanders in eastern Canada. Ibis 113 ( 1$): 42-58$.

Greenberg, R. E., S. L. Etter, and W. L. AnDERSON. 1972. Evaluation of proximal primary feather criteria for aging wild pheasants. J. Wildl. Manage. 36(3):700-705.

GreiJ, E. D. 1969. Plumage studies of the bluewinged teal, Anas discors L. Ph.D. Thesis. Iowa State Univ., Ames. 178pp.

Humphrey, P. S., and G. A. Clark, Jr. 1961. Pterylosis of the mallard duck. Condor 63(5): 365-385.

, AND 1964. The anatomy of waterfowl. Pages 167-232 in J. Delacour, ed. The waterfowl of the world. Vol. 4. Country Life Limited, London.

—, AND K. C. Parkes. 1959. An approach to the study of moults and plumages. Auk $76(1): 1-31$.

Kuroda, N. 1937. An examination on the individual variations among more than 1,000 teal. Tori 9(44):273-299.

Oring, L. W. 1968. Growth, molts, and plumages of the gadwall. Auk 85(3):355-380. 
Smart, M. G. 1962. Biological problems in the restocking of redhead ducks (Aythya americana). M.S. Thesis. Univ. of Missouri, Columbia. 115pp.

TAтsuoko, M. M. 1970. Discriminant analysis: the study of group differences. Selected topics in advanced statistics 6 . Inst. for Personality and Ability Testing. Champaign, Illinois. $57 \mathrm{pp}$.

Trauger, D. L. 1974. Eye color of female lesser scaup in relation to age. Auk $91(2): 243-$ 254.

Weller, M. W. 1957. Growth, weights, and Accepted 21 November 1974. plumages of the redhead, Aythya americana. Wilson Bull. 69(1):5-38.

- 1967. Notes on plumages and weights of the black-headed duck, Heteronetta atricapilla. Condor 69(2):133-145.

-1970. Additional notes on the plumage of the redhead (Aythya americana). Wilson Bull. 82(3):320-323.

Wishart, W. 1969. Age determination of pheasants by measurement of proximal primaries. J. Wildl. Manage. 33(3):714-717. 